\title{
The Impact of Central Bank of Nigeria Cashless Policy in Nigeria Economy
}

\author{
${ }^{1}$ Martin C. Ezeamama ${ }^{2}$ Nnamani Joseph Ndubuisi, ${ }^{3}$ Dr. (Mrs) Mary I. Marire, \\ ${ }^{4}$ Dr. C.C. Mgbodile \\ ${ }^{I}$ Dept of Banking and Finance, OSISATECH Polytechnic, Enugu \\ ${ }^{2}$ Department of Accountancy, OSISATECH Polytechnic, Enugu \\ ${ }^{3}$ Dept. of Business Management, Enugu State University of Science and Technology (ESUT) Enugu \\ ${ }^{4}$ Dept of Banking and Finance,Enugu State University of Science and Technology (ESUT) Enugu
}

\begin{abstract}
This paper studied the impact of cashless policy in Nigeria Economy. The policy was introduced by Central Bank of Nigeria (CBN) in December 2011 and was kick-started in Lagos in January 2012. Survey research was adopted with questionnaire as data collection instrument. Responses from the respondents show that cashless policy will increase employment; reduce cash related robbery thereby reducing risk of carrying cash; cashless policy will also reduce cash related corruption and attract more foreign investors to the country. The study, therefore, shows that the introduction of cashless economy in Nigeria can be seen as a step in the right direction. It is expected that its impact will be felt in modernization of Nigeria payment system, reduction in the cost of banking services, reduction in high security and safety risks and also curb banking related corruptions.
\end{abstract}

Keywords: Cashless economy, Cashless policy, Lagos State, Nigeria.

\section{Introduction}

Cashless economy is an economy where transaction can be done without necessarily carrying physical cash as a means of exchange of transaction but rather with the use of credit or debit card payment for goods and services. The cashless economy policy initiative of the Central Bank of Nigeria (CBN) is a move to improve the financial terrain but in the long run sustainability of the policy will be a function of endorsement and compliance by end-users (Ejiro, 2012). The CBN cash policy stipulates a daily cumulative limit of $\mathrm{N} 150,000$ and $\mathrm{N} 1,000,000$ on free cash withdrawals and lodgments by individual and corporate customers respectively in the Lagos State with effect from March 30, 2012. Individuals and corporate organizations that make cash transactions above the limits will be charged a service fee for amounts above the cumulative limits. Furthermore, 3rd party cheques above N150, 000 shall not be eligible for encashment over the counter with effect from January 1, 2012. Value for such cheques shall be received through the clearing house. All Nigerian banks were expected to cease cash in transit lodgment services rendered to merchant-customers from January 1, 2012.

The policy through the advanced use of information technology facilitates fund transfer, thereby reducing time wasted in Bank(s). Wizzit, a fast growing mobile banking company in South Africa has over three hundred thousand customers across South Africa. Likewise, M-PESA was introduced in Kenya as a small value electronic system that is accessible from ordinary mobile phones. It has experienced exceptional growth since its introduction by mobile phone operator (Safaricom) in Kenya in March, 2007 and has already been adopted by nine million customers, which is about $40 \%$ of Kenya's adult population. Wizzit and other mobile financial services including M- PESA in Kenya are helping low income Africans make financial transaction across long distance with their cell- phones, thereby reducing their travel cost and eliminating the risks of carrying cash and also avoiding most banking charges (Akintaro, 2012). It is assumed that the proper implementation of mobile phones and other technologies can aid the implementation of cashless policy and hence, the growth of cashless economy in Nigeria.

The introduction of the implementation of cashless policy (policy is program of actions adopted by government) began in Lagos State, Nigeria. Why Lagos? According to Central Bank of Nigeria (CBN, 2011) Lagos state accounted for $85 \%$ of POS and $66 \%$ of cheques transaction in Nigeria. Cashless economy aims at reducing the amount of physical cash circulating in the Nigeria economy and thereby encouraging more electronic-based transaction. According to Central Bank of Nigeria (CBN, 2011) the policy is expected to reduce cost incurred in maintaining cash-based economy by $90 \%$ upon its full implementation in Nigeria. This study aims to look at the impact of cashless economy in Nigeria. 


\section{Theoretical Background}

Cashless economy is not the complete absence of cash, it is an economic setting in which goods and services are bought and paid for through electronic media. According to Woodford (2003), Cashless economy is defined as one in which there are assumed to be no transactions frictions that can be reduced through the use of money balances, and that accordingly provide a reason for holding such balances even when they earn rate of return. In a cashless economy, how much cash in your wallet is practically irrelevant. You can pay for your purchases by any one of a plethora of credit cards or bank transfer (Roth, 2010). It has been observed that developed countries of the world, to a large extent, are moving away from paper payment instruments toward electronic ones, especially payment cards. Some aspects of the functioning of the cashless economy are enhanced by e-finance, e-money, e-brokering and e-exchanges. These all refer to how transactions and payments are effected in a cashless economy (Moses-Ashike, 2011). Marco and Bandiera (2004) argue that increased usage of cashless banking instruments strengthens monetary policy effectiveness and that the current level of e-money usage does not pose a threat to the stability of the financial system. However, it does conclude that central banks can lose control over monetary policy if the government does not run a responsible fiscal policy.

Echekoba and Ezu (2012), in a research carried out in Nigeria, observed that $68.2 \%$ of the respondent complained about long queues in the bank, $28.9 \%$ complained of bad attitude of teller officers (cashiers) while $2.89 \%$ complained of long distance of bank locations to their home or work places. Likewise, in her 24th NCS national conference in December 2011, CBN data shows that 51\% of withdrawal done in Nigeria was through automated teller machine (ATM), while 33.6\% was through over the counter (OTC) cash withdrawals and $13.6 \%$ through Cheques. Payment was also done through point of sales machine (POS) which accounted for $0.5 \%$ and web $1.3 \%$. Therefore, if the introduction of ATM in Nigeria cash withdrawals system reduced OTC withdrawal; then it will implies that introduction of cashless policy supported by application of information technology can achieve more to reduce over dependent on cash payment in Nigeria economy system.

However, Akhalumeh and Ohioka (2011) observed some challenges with the introduction of cashless policy. Their findings show that $34.0 \%$ of the respondents cited problem of internet fraud, $15.5 \%$ cited problem of limited POS/ATM, 19.6\% cited problem of illiteracy and 30.9\% stayed neutral - the respondent not been sure of problem been expected or experienced. While in some quarters there was fear of unemployment, some believe it will create more jobs especially when companies manufacturing POS machine are cited in Nigeria. More so, data sourced from Central Bank of Nigeria portal shows that Lagos state, with a population of 17 million people, only has sixty one Point Of Sales, twenty bank branches and twenty four ATMs per 100,000 people which are far less to satisfy the needs of the population. These data verify the claim of Echekoba and Ezu (2012) on the problem of cash based economy and cashless policy in Nigeria. For effective cashless implementation in Nigeria availability of sufficient and well-functioning infrastructure (notably electricity), harmonization of fiscal and monetary policy, regular assessment of the performance of cashless banking channels, consideration of the present state and structure of the economy, redesign of monetary policy framework and greater efforts towards economic growth whilst managing inflation should be considered (Odior and Banuso, 2012).

\section{Central Bank Of Nigeria: Questions And Answers On The Cbn Policy On Cash Withdrawal/Lodgement Limit}

Following the recent circular issued by the Central Bank of Nigeria, in collaboration with the Bankers Committee, placing cash withdrawal limits of N150,000 for individual account holders

and N1,000,000 for corporate account holders, with the aim of reducing the high dominance of cash in the Nigerian economy, we publish below some questions and answers that would further enlighten the public and other stakeholders on the essence of the policy.

\section{What Informed The New Policy Of Cash Withdrawal/Lodgement Limit?}

- The Nigerian economy is too heavily cash-oriented in transactions of goods and services. This is not in line with the global trend, considering Nigeria's ambition to be amongst the top 20 economies of the world by the year 2020.

- Furthermore, it is estimated that about $65 \%$ of the cash in circulation in the Nigerian economy is outside of the banking system, thus severely limiting the impact of the CBN's efforts at price and economic stabilisation.

- Also, the huge volume of cash transactions impose tremendous costs to the banking sector and, consequently, the customer, in terms of cash management, frequent printing of currency notes, currency sorting and cash movements.

- As the volume of cash in circulation (CIC) grows, so does the cost of cash management to the financial system which is estimated to reach N192billion in 2012. 
- There is also the risks involved in keeping or moving large amounts of cash, namely the high incidences of robberies and burglaries and the public's propensity to abuse and mishandle currency notes.

\section{What Does The CBN Want To Achieve With The Policy?}

- The CBN, in collaboration with the Bankers' Committee, aims to achieve an environment where a higher and increasing proportion of transactions are carried out through Cheques and Electronic Payments (epayments), in line with the global trend.

- The CBN recognises the need to balance the objectives of meeting genuine currency transaction demands and combating speculative market behaviours that may negatively affect economic growth and stabilisation measures.

- This new cash withdrawal policy will ensure that a larger proportion of currency in circulation is captured within the banking system, thereby enhancing the efficacy of monetary policy operations and economic stabilisation measures.

3. What Is The Global Trend? Is Nigeria In Line With Other Countries?

- Central Banks and other monetary authorities around the world have always strived to achieve a payment system that is tilted towards cheques and e-payment dominance, rather than cash-oriented.

- This helps in ensuring the effectiveness of stabilisation measures, keeps the currency in circulation clean and durable, and reduces the cost of cash management.

- Nigeria is a major economy in the world and certainly a leader on the African continent. In line with its vision 20:20, Nigeria should be at the forefront of economic modernisation.

4. How Will Placing A Limit On Cash Withdrawal Enhance The Efficacy Of Monetary Policy?

- Monetary policy operations will be enhanced in the sense that economic agents will resort to more use of Cheques and e-payments in carrying out daily transactions.

- This will result in a higher proportion of money in circulation being readily captured within the banking system.

- By implication, the CBN's stabilisation measures - either tightening or expansionary monetary policies to tackle inflation - will become more effective. For example, a change in interest rate will readily affect money supply because a larger volume of money supply is made up of currency in circulation which is mostly within the banking system.

5. What Are The Legal Implications Of The Cash Withdrawal Limit Policy?

- The policy does NOT in any way stop account holders from withdrawing any amount of money they desire from their accounts.

- The policy simply recognises that banking is a business and, as with any business, there are costs that are sometimes shared between the business and the customers.

- The policy stipulates that to withdraw more than N150,000 (for individual account holders) and more than $\mathrm{N} 1,000,000$ (for corporate account holders), there will be a nominal transaction cost, as stated in the circular.

6. Does The Policy Foreclose The Use Of Cheques In Transactions?

- The policy does not in any way preclude the use of Cheques as a means of payment. In fact, the policy rather encourages the use of Cheques as well as other e-payment methods in daily transactions.

7. How Would The Policy Help To Check High Rate Of Organised Crimes, Such As Armed Robbery, Kidnapping And Money Laundering?

- It is a well known fact that the criminal underworld usually requires huge volumes of cash to carry out their nefarious operations in order to avoid being traced or tracked.

- Therefore, placing a limit on the amount of cash flowing in the system, will curtail such activities as armed robbery, kidnapping, drug and gun running and money laundering.

- In an environment of extensive and predominant use of cheques and e- payments, criminal transactions can be easily traceable and tracked.

8. Will The Policy Have Negative Implications On Small Businesses That Heavily Rely On Cash Transactions? 
- In every human endeavour, attitudinal change often comes with some challenges, but that does not mean change is impossible, especially if it is for the good of all.

- Small businesses, with proper education and preparation, will be sensitised to the benefits of operating current accounts and adopting less cash-oriented methods in their business transactions.

- Data from Nigerian banks show that only about $10 \%$ of cash withdrawals from banks are of more than N100,000. Therefore, this new policy only affects $10 \%$ of banking customers who also account for over $75 \%$ of all banking transactions, thus accounting for the lion share of the cost of cash management.

9. Will The Policy Lead To People Resorting To The Old Habit Of Keeping Money In Their Homes?

- Most Nigerians are aware of the dangers of keeping their money at home, given the incidences of armed robbery, burglary, fire, etc.

- With the advent of electronic payment methods, these risks can be curtailed.

- The CBN, in collaboration with the Banks, will continue to educate and sensitise the masses on the advantages/benefits of e-payments as a modern, secure and efficient means of transaction, whilst also putting the infrastructures in place to ensure that e-payment services are within reach and available.

- Many people will endeavour to use ATM cards, Internet banking, Mobile banking, Point of Sale (POS), Cheques and other non-cash- based transactions, rather than be left behind.

10. Is The $10 \%$ Penalty For Exceeding The Withdrawal Limit Not Too Punitive? Will It Not Discourage The Public And Other Stakeholders' Support For The Policy?

- $10 \%$ is a transaction cost, and not meant to be punitive. It is simply a motivational factor aimed at driving the business of banking towards more efficient and cost-effective operations.

- The objective is to enable Nigerians see the policy as serving the interests of all concerned. The huge amount of money spent on frequent printing of currency notes and managing physical cash could be deployed in solving other pressing needs of the public.

11. Will The Policy Lead To A Win-Win Situation For The Regulator, The Operators And The Economic Agents?

- There is no doubt that the policy will lead to a win-win situation. It will also enhance effectiveness of monetary policy measures to curb inflation and stabilise the economy, it is in the interest of all, leading to economic growth and development that ultimately create jobs and improve economic wellbeing.

12. How Will The Policy Achieve The Desired Goal, Given The Huge Gaps In Infrastructure, Especially Electric Power Which Is Critical For Efficient E- Payment Operation?

- The gaps in infrastructure are a huge challenge to economic growth and modernisation in Nigeria. To this end, there are various efforts and initiatives currently in progress to address these gaps, particularly in power supply.

- Banks are also collaborating to participate in the CBN initiative of Shared Services, in order to share and lower infrastructure costs, which will go a long way to enhance infrastructure facilities and services in the banks.

- The CBN, in collaboration with the Banks, will continue to educate and sensitise the masses on the advantages/benefits of e-payments as a modern, secure and efficient means of transaction, whilst also putting the infrastructures in place to ensure that e-payment services are within reach and available.

13. Is It Possible For Banks To Lose Business Or See Reduced Patronage From The Public As A Result Of This New Policy?

- Banks will not lose customers since their infrastructure would have been improved before the commencement of the policy. The CBN, in collaboration with the Banks, will embark on a familiarisation program to educate the public on how the policy will be implemented, and the benefits of the policy to them as banking customers.

14. What Is The Modality Of Implementing This Policy?

- The CBN working with the banks will start the implementation of the policy in phases. There will be pilot schemes in Lagos, Port Harcourt, Abuja, Kano and Aba, which will eventually cover the entire country in few years to come.

- The pilot scheme will start with Lagos (code named Cashless Lagos), in which the CBN, the banks, relevant service providers and the Lagos State Government are working together to provide all the 
necessary infrastructure for the smooth takeoff of the scheme in Lagos State effective December 31, 2011.

- Towards achieving this, several committees consisting of all the major stakeholders are assiduously working to ensure that Cashless Lagos is achieved as planned.

\section{Overview Of Cashless Policy}

Money is often described as having three functions: (i) a unit of account function, (ii) a mediumof-exchange function, and (iii) a store-of-value function. In a cashless economy, the third is not operative and, probably, neither is the second. Cashless economy does not refer to an outright absence of cash transactions in the economic setting but one in which the amount of cash-based transactions are kept to the barest minimum. It is an economic system in which transactions are not done predominantly in exchange for actual cash (Daniel, D. G., R.

W. Swartz, and A. L. Fermar, (2004). A cashless society possesses the following characteristics;. All the money used is issued by private financial institutions (banks, and possibly other firms). It is conceivable that the central bank continues to operate like other banks, issuing its own deposits that could be used as money in the same way as other bank deposits are. However, in that case the central bank has no monopoly in the issue of Money. In a cashless society the unit of account (e.g. Dollar, euro) remains a national affair and is provided by the state. The followings among others enhance the functioning of cashless economy; efinance, e-banking, e-money, e- brokering, e-exchanges etc .In a modern economy, the use of noncash payment methods such as cards (credit and debit) dominates the use of cash in payments.

The card based payment system has several players. On the one hand, are the providers of the card based payment system- first of which is the card companies like MasterCard and Visa who provide their payment network for the system to function. The second set of providers are the banks that act as acquirers for merchants and issuers for cardholders and reach the card payment services to the ultimate users. For these two parties, the card payment system is an income generating initiative and they are motivated to run the system as they are able to generate adequate profits out of their operations. On the other side of the system are the users- both merchants and cardholders. The benefits these two players derive from the system are manifold- the convenience of electronic transactions, the ease of credit availability, increased sales, increased purchasing power, to list a few. Since they are the end users of the convenience the card payment system generates, they are the ones who bear the cost of the system. Apart from these four players there is the regulator of the payment system, usually the central bank of the country. The card based payment system cannot function in absence of any of its players. The global volume of non-cash transactions totaled 260 billion in 2009 ( world payments report 2011), after sustained average annual gains of 6.8\% since 2001. The outright volume of these payments only remains heavily concentrated in developed markets. Developing countries are just improving their payments infrastructures, enabling wider adoption and greater usage of non-cash means and channels. They also tend to be open to innovations that can broaden their still-nascent base of users (world payments report 2011). However, the global use of cash payment is still endemic, especially for low-value retail transactions. But while cash may be convenient, it makes taxation less transparent, and it is costly to distribute, manage, handle and process. It therefore follows that; cash as a mode of payment is an expensive proposition for any government. As a result, many governments are seeking to reduce these costs and encourage the use of non-cash payment means. The Nigerian economy is too heavily cash oriented in its transaction of goods and services and this is not in line with global trend, considering Nigeria's ambition to be amongst the top 20 economies of the world by the year 2020.For instance an overview of central bank of Nigeria policies on cash management in Nigeria's financial system is high and increasing; direct cost of cash is estimated to reach one hundred and ninety two billion naira in 2012 (CBN 2011). See the figure below;

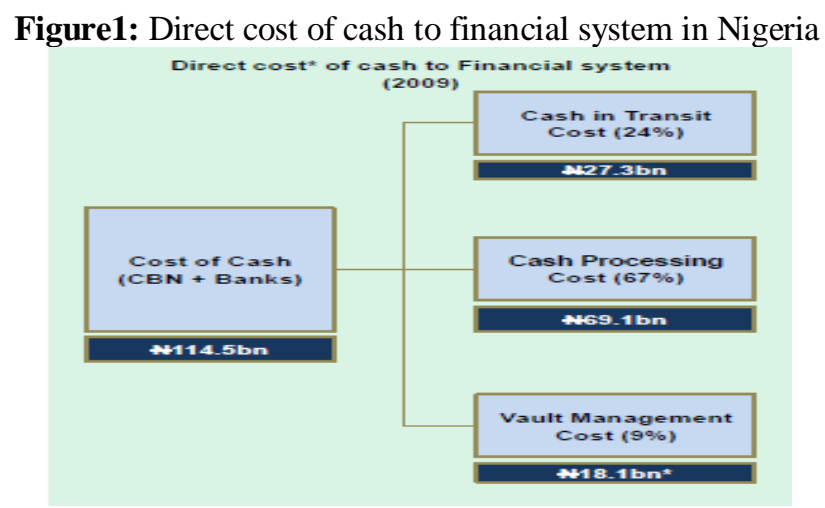


Source: Central Bank of Nigeria Annual Report 2011

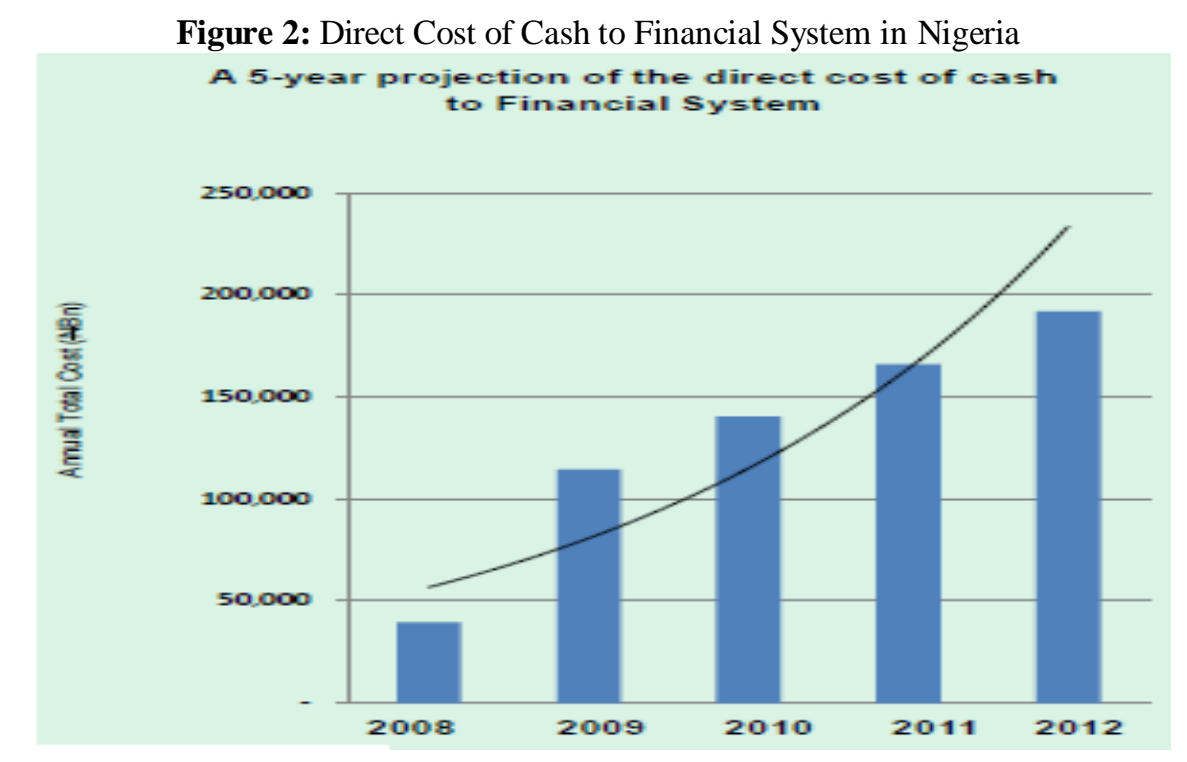

Source: Central Bank of Nigeria Annual Report 2011

As it is now, cash transactions in Nigeria represent over ninety -nine percent of customer activities in Nigerian banks today, see the table below;

Table1: Payment Channels in Nigeria in 2011

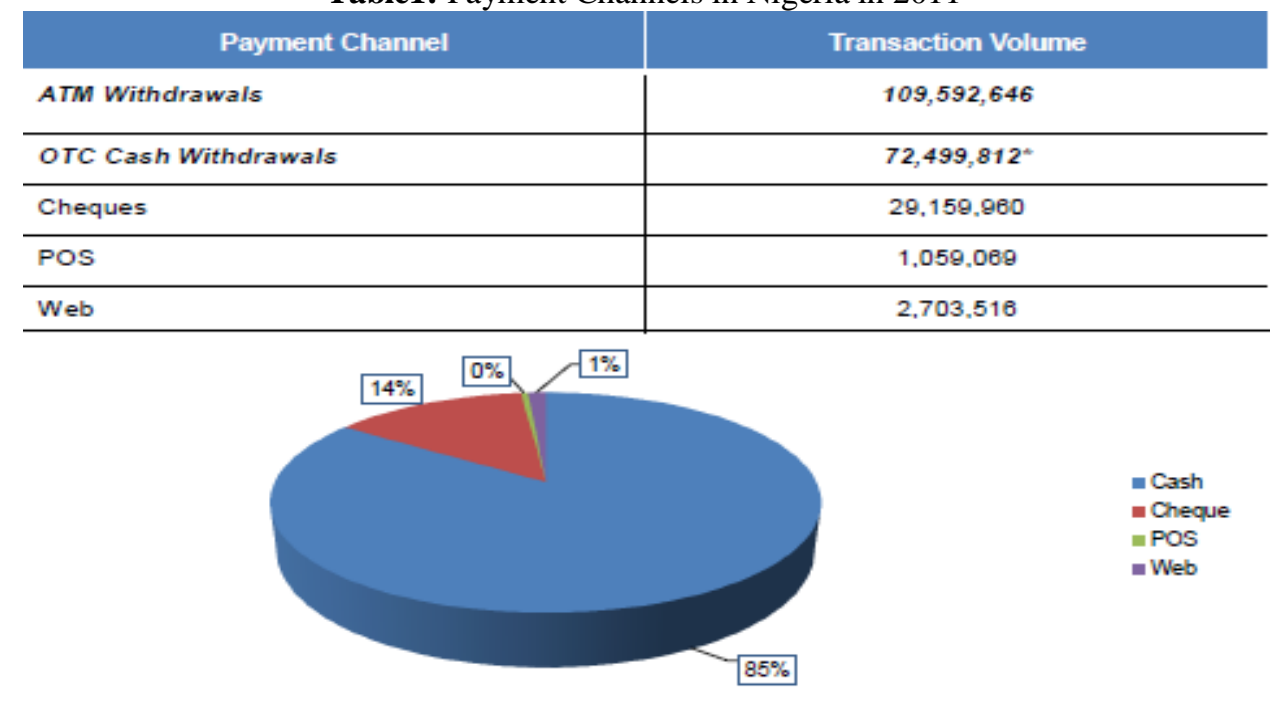

Source: Central Bank of Nigeria Annual Report 2011 The new cash policy was introduced for a number of key reasons, including:

1. To drive development and modernization of our payment system in line with Nigeria's vision 2020 goal of

2. being amongst the top 20 economies by the year 2020. An efficient and modern payment system is positively correlated with economic development, and is a key enabler for economic growth.

3. To reduce the cost of banking services (including cost of credit) and drive financial inclusion by providing more efficient transaction options and greater reach.

4. To improve the effectiveness of monetary policy in managing inflation and driving economic growth.

In addition, the cash policy aims to curb some of the negative consequences associated with the high usage of physical cash in the economy, including:

\section{High Cost Of Cash}

There is a high cost of cash along the value chain - from the CBN \& the banks, to corporations 
and traders; everyone bears the high costs associated with volume cash handling.

\section{High Risk Of Using Cash}

Cash encourages robberies and other cash-related crimes. It also can lead to financial loss in the case of fire and flooding incidents.

\section{High Subsidy}

CBN analysis showed that only 10percent of daily banking transactions are above 150k, but the 10percent account for majority of the high value transactions. This suggests that the entire banking population subsidizes the costs that the tiny minority 10percent incur in terms of high cash usage.

\section{Informal Economy}

High cash usage results in a lot of money outside the formal economy, thus limiting the effectiveness of monetary policy in managing inflation and encouraging economic growth.

\section{Inefficiency \& Corruption}

High cash usage enables corruption, leakages and money laundering, amongst other cash-related fraudulent activities.

\section{Stylized Facts}

Nigeria is largely a cash-based economy with large percentage of funds residing outside the banking sector $(66 \%)$ as against the developed world where the money in circulation is for example 4 percent in US and 9 percent in touch cash

U.K. (Ovia 2002). The cash-based economy is characterized by the psychology to physically hold and

;(a culture informed by ignorance, illiteracy, and lack of security consciousness and appreciation of the merit of digital payment ). The currency in circulation in Nigeria (CIC) at end of December 2011 stood at N1,565.76 billion, representing an increase of 13.6 per cent over the level in 2010.The growth in $\mathrm{CIC}$ reflected the high dominance of cash in the economy as well as an increase in economic activities. The denominational breakdown of the currency in circulation between 2007 and 2011as well as currency in circulation are as shown below:

Table3: Currency in Circulation in Nigeria 2007-2011

\begin{tabular}{|c|c|c|c|c|c|c|c|c|c|c|}
\hline \multirow[b]{3}{*}{ Coins } & \multicolumn{2}{|l|}{2007} & \multicolumn{2}{|l|}{2008} & \multicolumn{2}{|l|}{2009} & \multicolumn{2}{|l|}{2010} & \multicolumn{2}{|l|}{2011} \\
\hline & \multirow{2}{*}{$\begin{array}{l}\text { Volume } \\
\text { (million) }\end{array}$} & \multirow{2}{*}{$\begin{array}{c}\text { Value } \\
\text { ( } \$ \text { billion) }\end{array}$} & \multirow{2}{*}{$\begin{array}{l}\text { Volume } \\
\text { (million) }\end{array}$} & \multirow{2}{*}{$\begin{array}{c}\text { Value } \\
\text { ( } \mathrm{N} \text { billion) }\end{array}$} & \multirow{2}{*}{$\begin{array}{l}\text { Volume } \\
\text { (million) }\end{array}$} & \multirow{2}{*}{$\begin{array}{c}\text { Value } \\
\text { ( } \$ \text { billion) }\end{array}$} & \multirow{2}{*}{$\begin{array}{l}\text { Volume } \\
\text { (million) }\end{array}$} & \multirow{2}{*}{\begin{tabular}{|c|} 
Value \\
( $\$$ billion)
\end{tabular}} & \multirow{2}{*}{$\begin{array}{l}\text { Volume } \\
\text { (million) }\end{array}$} & \multirow{2}{*}{$\begin{array}{c}\text { Value } \\
\text { ( } \$ \text { billion) }\end{array}$} \\
\hline & & & & & & & & & & \\
\hline$\star * 2$ & 81.9 & 0.16 & 104.5 & 0.21 & 114.5 & 228.9 & 107.83 & 0.22 & 107.87 & 0.22 \\
\hline+41 & 615.4 & 0.62 & 532.2 & 0.53 & 490.6 & 490.65 & 530.11 & 0.53 & 581.23 & 0.58 \\
\hline $50 \mathrm{k}$ & 738.3 & 0.37 & 463.1 & 0.23 & 454.5 & 227.26 & 434.48 & 0.22 & 529.72 & 0.26 \\
\hline $25 \mathrm{k}$ & 19 & 0.01 & 240.6 & 0.06 & 212 & 53 & 196.53 & 0.049 & 339.12 & 0.08 \\
\hline $10 \mathrm{k}$ & 2.2 & 0.0002 & 235.1 & 0.02 & 228.3 & 228.82 & 212.82 & 0.021 & 302.89 & 0.03 \\
\hline $1 \mathrm{k}$ & 0 & 0 & 51.2 & 0.0005 & 57.4 & 0.57 & 48.74 & 0.0048 & 12.75 & 0.08 \\
\hline Sub Total & $1,456.80$ & 1.15 & $1,629.70$ & 1.06 & $1,557.30$ & $1,023.20$ & $1,530.51$ & 1.04 & $1,873.58$ & 1.26 \\
\hline \multicolumn{11}{|l|}{ Notes } \\
\hline$A 1000$ & 264.4 & 264.4 & 572.9 & 572.91 & 584.4 & 584.39 & 663.76 & 663.7 & 959.45 & 959.45 \\
\hline$A 500$ & 707.2 & 353.6 & 801.9 & 400.93 & 852.8 & 426.4 & $1,027.78$ & 513.89 & 726.22 & 363.10 \\
\hline $\mathrm{A}+200$ & $1,256.00$ & 251.3 & 571.6 & 114.32 & 491.9 & 98.38 & 501.27 & 100.25 & 621.75 & 124.31 \\
\hline$A 100$ & 494.9 & 49.5 & 323.6 & 32.36 & 350 & 35 & 341.12 & 34.11 & 507.90 & 50.77 \\
\hline$A 450$ & 351.3 & 17.6 & 228 & 11.4 & 344.9 & 17.25 & 782.27 & 39.11 & 777.94 & 38.89 \\
\hline $\mathrm{A} 2 \mathrm{2O}$ & 823 & 16.5 & 827.3 & 16.55 & 769.5 & 15.39 & 752.65 & 15.1 & 788.67 & 15.77 \\
\hline $\mathrm{A} 10$ & 355.9 & 3.6 & 283.2 & 2.83 & 285.5 & 2.85 & 680.61 & 6.81 & 789.13 & 7.89 \\
\hline A45 & 579 & 2.9 & 533.1 & 2.67 & 720.5 & 3.6 & 837.93 & 4.19 & 865.38 & 4.33 \\
\hline Sub-Total & $4,831.70$ & 959.4 & $4,141.60$ & $1,153.97$ & $4,399.50$ & $1,183.27$ & $5,587.39$ & $1,377.16$ & $6,036.43$ & $1,564.50$ \\
\hline Total & $6,288.50$ & 960.55 & $5,768.30$ & $1,155.03$ & $5,956.80$ & $1,184.30$ & $7,117.90$ & $1,378.20$ & $7,910.01$ & $1,565.76$ \\
\hline
\end{tabular}

Source: Central Bank of Nigeria Annual Report 2011 


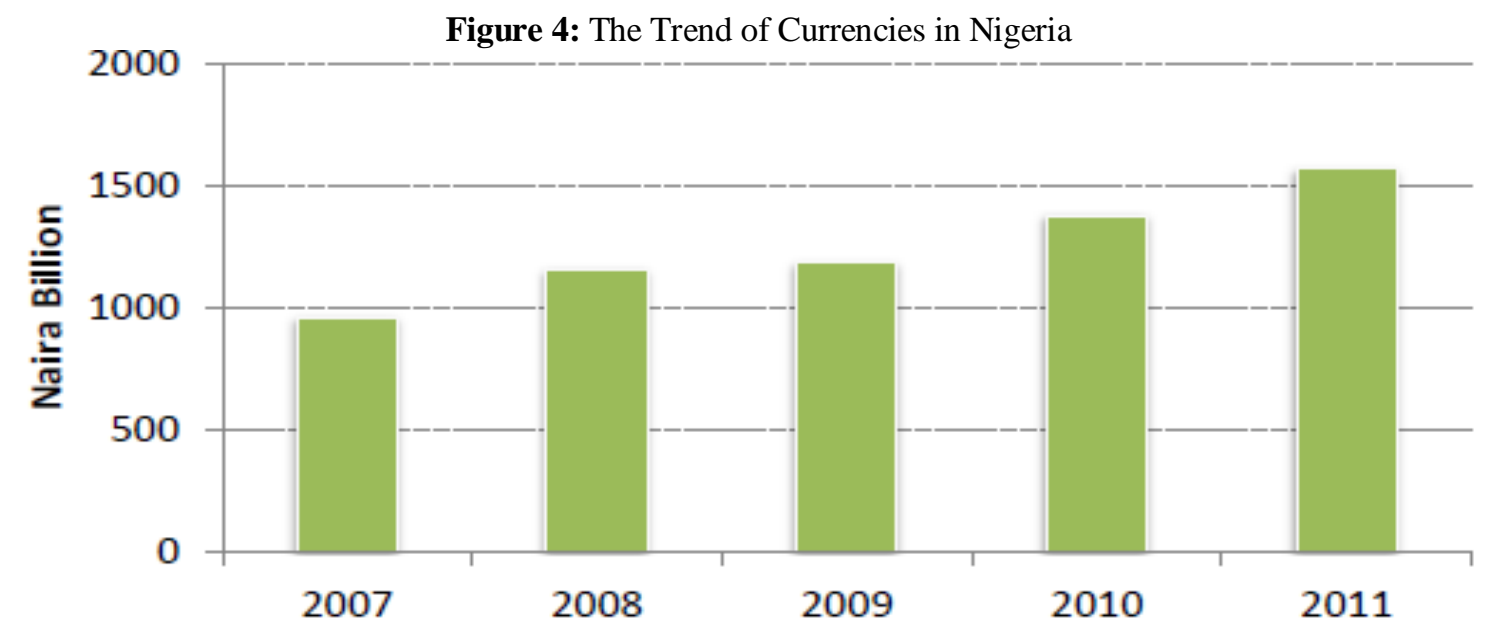

Source: Central Bank of Nigeria Annual Report 2011

Cash is an integral element that fuels that several vices in Nigeria. This is as illustrated below;

Figure 5: Vices Associated With Cash Transaction in Nigeria

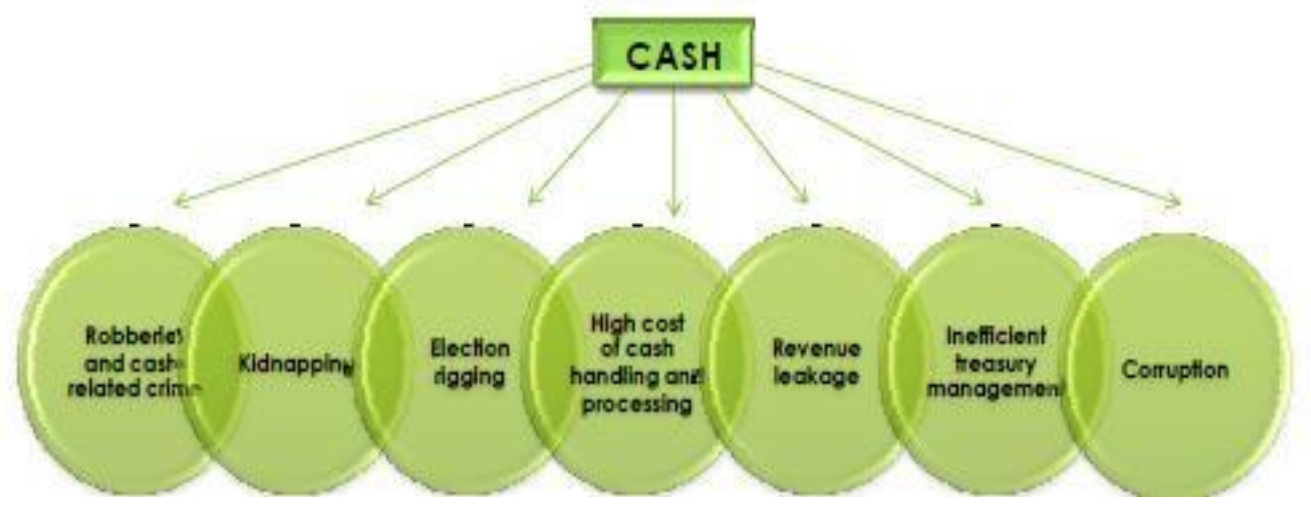

Source: Central Bank of Nigeria Annual Report 2011

From the foregoing, an alternative payment channels will have considerable positive consequences on the Nigeria economy. To this end, the Nigerian financial system is witnessing a redirection, with the Central Bank of Nigeria's (CBN) latest effort called the Cashless policy initiative, which commenced with Lagos on January 1,2012 , as a pilot scheme.

Today, Nigeria electronic payment (e-payment)landscape is on a new threshold with banks, switching and transaction companies, vendors of Automated Teller Machine (atms), Point of sale (POS) and third party companies all jostling to expand the scope of market .For instance according to CBN reports; The volume and value of electronic card (e-card) transactions has increased significantly from 195,525,568 and N1,072.9 billion in 2010 to 355,252,401 and N1,671.4 billion, in 2011 reflecting an increase of 81.5 and 55.8 per cent, respectively. The increase was attributed to enhanced public confidence in electronic card payments

In addition, data on various e-payment channels from another CBN reports indicated that atms remained the most patronized, accounting for 97.8 per cent, followed by web payments, 1.0 per cent, Point-ofSale (POS) terminals, and mobile payments, 0.6 per cent each. Similarly, in value terms, atms accounted for 93.4 per cent, web 3.5 per cent, POS 1.9 per cent and mobile payments, 1.2 per cent.

The number of atms stood at 9,640, while the volume and value of transactions amounted to $347,569,999$ and N1,561.75 billion, at end-December 2011, respectively. These figures reflected increases of 86.7 and 63.7 per cent respectively over the volume and value of 186,153,142 and N954.04 billion, at endDecember 2010. The volume and value of mobile payments increased by 215.6 and 185.8 per cent from 1,156,553 and N6.7 billion to 3,649,374 and N19.0 billion, respectively, at end-December 2011.The table below shows the market share in the e-payment market in Nigeria between 2008 to 2011 
Table 5: Market Share in the e-Payment Market in Nigeria

\begin{tabular}{|l|c|c|c|c|c|c|c|c|}
\hline \multicolumn{7}{|c|}{ Table 5: Market Share in the e-Payment Market in } \\
\hline e-Payment & \multicolumn{3}{|c|}{ Volume (Millions) } & \multicolumn{5}{c|}{ Value (N ' Billion) } \\
\hline Segment & 2008 & 2009 & 2010 & 2011 & 2008 & 2009 & 2010 & 2011 \\
\hline ATM & 60.1 & 109.6 & 186.2 & 347.6 & 399.7 & 548.6 & 954.0 & 1561.8 \\
\hline \% of Total & 91.0 & 95.3 & 95.1 & 97.9 & 9.5 & 85.0 & 88.9 & 93.4 \\
\hline Web (internet) & 1.6 & 2.7 & 7.2 & 3.6 & 25.1 & 84.2 & 99.5 & 58.0 \\
\hline \% of Total & 2.4 & 2.3 & 3.7 & 1.0 & 5.7 & 13.1 & 9.3 & 3.5 \\
\hline POS & 1.2 & 0.9 & 1.1 & 2.1 & 16.1 & 11.0 & 12.7 & 31.0 \\
\hline \% of Total & 1.8 & 0.8 & 0.6 & 0.6 & 3.7 & 1.7 & 1.2 & 1.9 \\
\hline Mobile & 3.2 & 1.8 & 1.2 & 1.9 & 0.7 & 1.3 & 6.7 & 20.5 \\
\hline \% of Total & 4.8 & 1.6 & 0.6 & 0.5 & 0.1 & 0.2 & 0.6 & 1.2 \\
\hline TOTAL & 66.1 & 115.0 & 195.7 & 355.2 & 441.6 & 645.1 & 1072.9 & 1671.4 \\
\hline
\end{tabular}

Source: Central Bank of Nigeria Annual Report 2011

The figures below reveal the volume of electronic card-based transactions as well as the value of such in 2011, the year the cashless policy initiative was conceived;

Fig.6: Volume of Electronic Card-Based Transactions in Nigeria in 2011

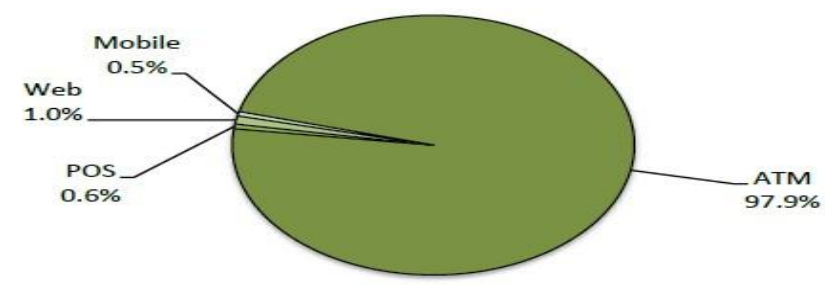

Source: Central Bank of Nigeria Annual Report 2011

Fig.7: Value of Electronic Card-Based Transactions in Nigeria in 2011

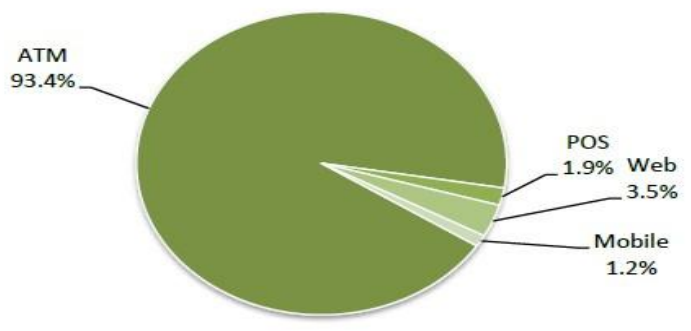

Source: Central Bank of Nigeria Annual Report 2011

The descriptive analyses above show that Nigeria has been using electronic payment systems for many years now, and as such the country payment system is rapidly transiting to more and more IT based systems. Increased non- cash payments have implications that are not small. The payment system is a significant national infrastructure and is critical to the growth of the national economy just like telecommunication, electrical power, and transportation infrastructures are. Furthermore, an electronic payment system has the ability to track individual spending; to facilitate the design of products by the banks. This information is also useful to the government when making economic decisions. It logically follows therefore that efficient payment system is a prerequisite for the development of the national economy. A research work carried out by Visa Canada Association in collaboration with Global Insight (A leading economic and financial consulting firm) revealed that electronic payments provide transactional efficiency to consumers, merchants, banks and the economy. Electronic payments have contributed

\$C 107 billion to the Canadian economy since 1983 and represents nearly 25\% of the \$C 437 billion cumulative growth in the Canadian economy over the same period. Automating and streamlining electronic 
payments made from self-serve channels such as ATMs, branch office terminals and point-of-sale (POS) systems can reduce paper-based errors and costs.

An efficient payments system will depend less on cash, and has great potential to grow the national economy. According to (Cobb, 2005), efficient safe and convenient electronic payments carry with them a significant range of macro-economic benefits. - The impact of introducing electronic payments is akin to using the gears on a bicycle. Add an efficient electronic payments system to an economy, and you kick it into a higher gear. Add better-controlled consumer and business credit, and you notch up economic velocity even further. $\square$ (Cobb, 2005)

.In Nigeria, moving from a society where $66 \%$ of cash is held outside of the banks to a cashless society is a big change. It is therefore an enormous challenge for the government, financial institutions, individuals and other stakeholders responsible to make the system achieve its economic benefits.

\section{Research Methodology}

This study was carried out, using accidental sampling method, in Lagos state, Nigeria. A total of 500 traders, students and civil servants were sampled. Questionnaire was used as data collection instrument, with questions on demographics and benefits of cashless economy in Nigeria. The major statistical technique used was descriptive (use of frequency tables and charts).

\section{Results}

\section{Demographics}

Responses on gender show that male respondents accounted for $55.6 \%$ while the female respondents are $44.4 \%$. Figure 1 and Figure 2 presents the responses on age and occupation, respectively. For age, majority of the respondents are between 18 to 25 years, this is followed by those between 26 to 40 years while the least number are between 41 to 60 years. For occupation of the respondents, the highest percentage $(44.4 \%)$ is traders, followed by students $(33.3 \%)$ and civil servants $(22.2 \%)$.

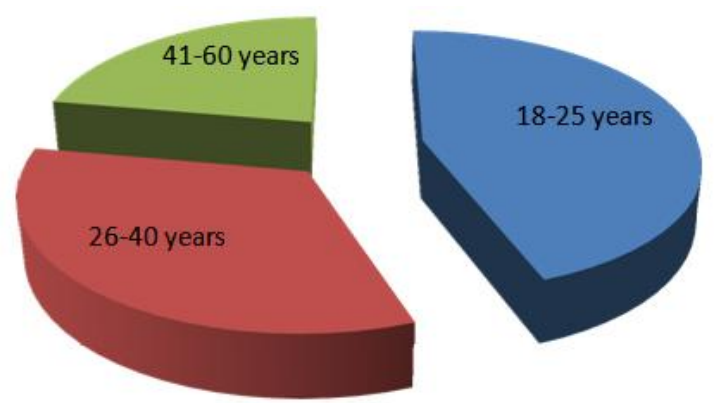

Figure 8: Age of Respondents

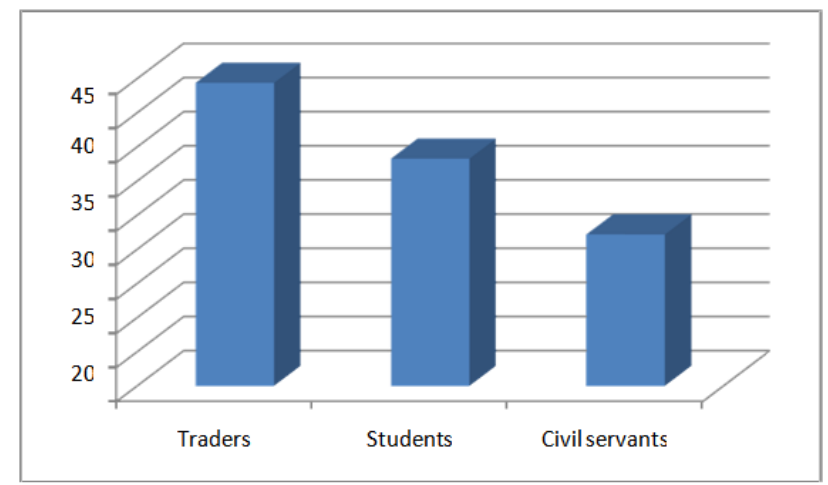

Figure 9: Occupation of Respondents

\section{Benefits}

Table 1 shows the view of respondents on benefits of cashless economy in Nigeria. The lowest percentage, $11.1 \%$ of the respondents, believed that cashless policy will increase employment. A higher percentage, $22.2 \%$ of the respondents, believed that cashless policy in Nigeria will reduce cash related robbery thereby reducing risk of carrying cash. The highest percentage of the respondents believed that cashless policy will reduce cash related corruption $(33.3 \%)$ and cashless policy will attract more foreign investors to the country $(33.3 \%)$. 
Table 6: Benefits of Cashless Economy in

\begin{tabular}{cc}
\hline Benefits of Cashless Economv & Percentage (\%) \\
\hline Increase employment & $11.1 \%$ \\
Reduce cash related robbery & $22.2 \%$ \\
Reduce cash related corruption & $33.3 \%$ \\
Attract more foreign investment & $33.3 \%$ \\
Total & $100 \%$ \\
\hline
\end{tabular}

\section{Conclusion}

The study, impact of cashless economy in Nigeria, focused on the three major categories by which Nigerians can be divided - traders, students and civil servants. More number of traders was sampled, compared to students and civil servants, because they are more into business and financial transactions. More so, a higher number of respondents within the age bracket of 18 and 25 years show that apart from students, quite a number of Nigerian youth are also into trade.

This study shows that the introduction of cashless economy in Nigeria can be seen as a step in the right direction. It is expected that its impact will be felt in modernization of Nigeria payment system, reduction in the cost of banking services as well as reduction in high security and safety risks. This should also include curbing banking related corruptions and fostering transparency.

It is also assumed that the introduction of cashless policy in Nigeria will help to reduce the amount of bills and notes circulating in the economy. This should, therefore, reduce handling operation cost incurred on conventional money, as well as reduction in cash related crimes. It should also help to provide easy access to banking services for Nigerians.

\section{References}

[1]. Akhalumeh, P.B., and Ohiokha, F. (2011): Nigeria's Cashless Economy; The Imperatives. International Journal of Management \& Business Studies. vol.2 pp. $12-17$.

[2]. Akintaro, S. (2012): Going Cashless. IT \& Telecom digest, online magazine, august,2012

[3]. CENTRAL BANK OF NIGERIA (2011): Towards a Cashless Nigeria: Tools \& Strategies. Nigerian Journal of Economy. 3(2), $344-350$.

[4]. Echekoba, F.N., and Ezu, G.K. (2012): Electronic Retail Payment Systems: User Acceptability \& Payment Problems in Nigeria. Arabian Journal of Business \& Management Review. vol.5, pp. 60 - 63

[5]. Ejiro, O. (2012): What Nigerians Think of the Cashless Economy Policy. Nigerian Journal of Economy. $4(6), 97$ - 102.

[6]. Humphrey, D. B. (2004): -Replacement of cash by cards in U.S. Consumer Payments, Journal of Economics and Business, 56, $211-225$.

[7]. Marco, A. and L. Bandiera (2004): -Monetary Policy, Monetary Areas and Financial Development with Electronic Money, IMF Working Study, IMF.

[8]. Moses-Ashike, H. (2011), “Cashless Economic can Reduce Risk of Carrying Huge Cash”, [Online] Available: http://www.businessdayonline.com/.../22217.

[9]. Odior, E.S., and Banuso, F.B. (2012): Cashless Banking in Nigeria: Challenges, Benefits \& Policy Implications.

[10]. European Scientific Journal. Vol 8, pp. $12-16$.

[11]. Roth, B. L. (2010). "The Future of Money: The Cashless Economy - Part 1". [Online] Available: https://www.x.com/.../futuremoney-cashless-economy-part-i.

[12]. Woodford M. (2003). "Interest \& Price: Foundation of a Theory of Monetary Policy", Princeton University Press.

[13]. Ajayi, S. I. and O. O. Ojo (2006), -Money and Banking: Analysis and Policy in the Nigerian Context, Second Edition, University of Ibadan, Daily Graphics Nigeria Ltd.

[14]. Al Shaikh, Said (2005 http://www.ameinfo.com/53472.html

[15]. Alan Greenspan (2007), - The Age of Turbulence $\square$, Adventures in a New World

[16]. Asokan,N, Janson, P., Steiner, M. and Weidner, M. ( 2000)Electronic Payment Systems IBM Research Division, Zurich Research Laboratory p1-16

[17]. Baddeley, M. (2004), —Using E-Cash in the New Economy: An Economic Analysis of Micropayment Systems $\square$, Journal of Electronic Commerce Research, Vol. 5, No.4, UK, Cambridge.

[18]. Central Bank of Nigeria (2011), Money Market Indicators \& Money and Credit Statistics, CBN Statistical Bulletin, CBN Publications

[19]. Central Bank of Nigeria Website (2011), - New Cash Policy, Presentation for the Interactive

[20]. Claudia, C. and P. De Grauwe (2001): - Monetary Policy in a Cashless Society $\square$, Brussels, CEPR Discussion Study. Cobb Anne (2004), http://www.ameinfo.com/50050.html

[21]. Commonwealth Business Council (2004) A white paper publication on payment solutions for modernising economies. Daniel, D. G., R. W. Swartz, and A. L. Fermar, (2004): -Economics of a Cashless Society: An Analysis of Costs and

[22]. Benefits of Payment Instruments $\square$,AEI-Brookings Joint Center

[23]. Edward J., Payment Arrangements and Inflation, American Economic Review Papers and Proceeding 92 (2002), 51-57. European Central Bank, (1998), Report on Electronic Money, Frankfurt, August.

[24]. Federico Fiallos, Liying Wu (2005) Digital Money: Future Trends and Impact on Banking, Financial Institutions, and e Business.

[25]. Gali, J., and L. Gambetti (2009), -On the Sources of the Great Moderation, American Economic Journal: Macroeconomics, 1, 2657.14

[26]. Garcia-Swartz, Daniel \& Hahn, Robert \& Layne-Farrar, Anne (2006a). The Move Toward a Cashless Society: A Closer Look at Payment Instrument Economics. Review of Network Economics, Vol. 5, Issue 2. (Jun. 2006), pp. 175-198.

[27]. Garcia-Swartz, Daniel \& Hahn, Robert \& Layne-Farrar, Anne (2006b). The Move Toward a Cashless Society: Calculating the 
Costs and Benefits. Review of Network Economics, Vol. 5, Issue 2. (Jun. 2006), pp. 199-228.

[28]. Hord, Jennifer (2005) http://communication.howstuffworks.com/electronic-payment2.htm http://www.richmondfed.org/news

[29]. Humphrey, D. B. (2004): —Replacement of cash by cards in U.S. Consumer Payments, Journal of Economics and Business, 56, 211-225.

[30]. Humphrey, D. B. and A. N. Berger (1990): - Market Failure and Resource Use: Economic Incentives to Use Different Payment Instruments $\square$., New York, Monograph Series in Finance and Economics.

[31]. Humphrey, D. B., L. B. Pulley and J. M. Vesala, (1996): -Cash, Study and Electronic Payments: A Cross Country Analysis $\square$,Journal of Money, Credit and Banking, Vol.

[32]. Humphrey, David \& Berger, Allen (1990). "Market Failure and Resource Use: Economic Incentives to Use Different Payment Instruments". David B. Humphrey (ed.), The U.S. Payment System: Efficiency, Risk and the Role of the Federal Reserve. Kluwer Academic Publishers: Boston, MA.

[33]. Kalakota, R., \& Whinston, A. B. (1997). Electronic commerce: A manager's guide, Reading, MA: Addison Wesley Longman.

[34]. Kriwoluzky A. and C. A. Stoltenberg (2010): -Money and Reality $\square$;Department of Economics, University of Amsterdam. Lacker, J.M. (2005), -Payment Economics and the Role of the Central Banks"

[35]. Lubik, T. A., and F. Schorfheide (2004): -Testing for Indeterminacy: An Application to U.S. Monetary Policy, American Economic Review, 94(1), 190-217.

[36]. Marco, A. and L. Bandiera (2004): -Monetary Policy, Monetary Areas and Financial Development with Electronic Money $\square$, IMF Working Study, IMF.

[37]. Microfinance Nigeria (2010), A Paper titled Poor Infrastructure, low awareness may hamper e- payments drive Moody‘s Analytics (2010) The impact of electronic payments on economic growth.

[38]. Neuman, B. C. \& Medvinsky, G. (1996). NetCheque, NetCash, and the Characteristics of Internet Payment Services. The Journal of Electronic Publishing, Vol. 2, Issue 1

[39]. Patinkin, D. (1965): -Money, Interest and Prices $\square$, Second Edition, New York, Harper and Row Stock, J. H., and M. W. Watson (2002): - Has the Business Cycle Changed and Why?

[40]. Taddesse W \& Kidan T (2005) e-payment: Challenges \& Opportunities in Ethiopia

[41]. Vassilliou, Charalampos (2004) Electronic Payment Systems and Marketing: A literature review

[42]. Worku, G (2010) Electronic Banking in Ethiopia - Practices, Opportunities and Challenges. Journal of Internet Banking \& Commerce, August 2010,Vol. 12 No.2 